\title{
Znaczenie energii odnawialnej w polityce eurośródziemnomorskiej - uwarunkowania i perspektywy rozwoju
}

Unia Europejska od początku funkcjonowania traktuje obszar śródziemnomorski priorytetowo ze względu na doświadczenia epoki kolonialnej, gdzie większość państw regionu była w całości lub w części uzależniona od europejskich potegg, bliskość geograficzna, z której wynikają obawy o bezpieczeństwo kontynentu oraz problem nielegalnej imigracji ze względu na niestabilną sytuację polityczną w południowej i wschodniej części basenu Morza Śródziemnego oraz zależności ekonomiczne, gdzie Europa jest głównym partnerem gospodarczym państw regionu ${ }^{1}$. Od 1995 roku Unia Europejska stworzyła cały szereg instrumentów i programów dedykowanych państwom śródziemnomorskim, z których najważniejsze to Partnerstwo Eurośródziemnomorskie, program Europejskiej Polityki Sąsiedztwa, inicjatywa Unia dla Śródziemnomorza. Chociaż różne pod względem struktury, finansowania, zakresu podmiotowego, wszystkie miały na celu stabilizację i rozwój gospodarczy regionu, przy jednoczesnej promocji modelu państwa liberalno-demokratycznego na wzór europejski w państwach partnerskich.

Współpraca energetyczna jest jedną z ważniejszych w ramach eurośródziemnomorskiej agendy. Państwa śródziemnomorskie odgrywają znaczną rolę $w$ dostawach ropy i gazu do Europy zarówno jako bezpośredni eksporterzy, jak i terytoria tranzytowe, posiadają również wysoki potencjał rozwoju sektora energii odnawialnej (OZE). Państwa europejskie są największym światowym importerem energii, kupując za granicą $80 \%$ ropy i $60 \%$ gazu (Doğuşhan Kara, 2014, s. 7). Większość potrzeb energetycznych Unii zaspokajają europejscy eksporterzy, Norwegia i Rosja. Z państw śródziemnomorskich ropa i gaz transportowane są głównie z Algierii i Libii. W 2013 roku udział Algierii w unijnym imporcie gazu wynosił 13\%. Największymi odbiorcami są Portugalia, Hiszpania, Włochy oraz Francja. Udział Libii w imporcie ropy do Europy wynosił w tym samym okresie $10 \%$, a głównymi odbiorcami są Włochy, Francja i Hiszpania. Prognozy międzynarodowych instytucji wskazuja, iż uzależnienie Europy od zewnętrznych dostaw surowców naturalnych będzie się zwiększać w najbliższych latach. Dlatego też, jednym z elementów strategii energetycznej Europy, ściśle związanej

Państwa śródziemmomorskie objęte inicjatywami Unii Europejskiej: Algieria, Egipt, Maroko, Liban, Libia - jako obserwator, Syria, Jordania, Autonomia Palestyńska, Izrael. Turcja uczestniczyla w Partnerstwie Eurośródziemnomorskim od 1995 roku w 2008 roku została zaproszona do udziału w Unii dla Śródziemnomorza. Program EPS nie jest dostępny dla Turcji z uwagi na negocjacje akcesyjne. W niniejszym artykule nie uwzględniono Izraela oraz Turcji. Więcej na temat wspólpracy eurośródziemnomorskiej zob. Zając, 2010. 
$z$ bezpieczeństwem energetycznym, jest dywersyfikacja sektora energetycznego, $w$ tym poprzez zwiększenie produkcji i zużycia energii pochodzącej ze źródeł odnawialnych ${ }^{1}$. Pozyskanie jej planowane jest zarówno z krajowej produkcji poszczególnych państw, jak i poprzez import, ze względu na bliskość geograficzną, rozwinięte instytucje współpracy oraz potencjał, państwa śródziemnomorskie zajmuja tutaj priorytetowe miejsce.

\section{Cele UE w zakresie OZE}

Unia Europejska posiada duże doświadczenie w zakresie badań nad OZE oraz promocji tego sektora. Szerzej nad bezpieczeństwem energetycznym i uzależnieniem państw europejskich od zewnętrznych dostaw ropy i gazu zaczęto dyskutować od połowy lat 70-tych. Już w rok po kryzysie naftowym Wspólnota przyjęła dokument dotyczący strategii energetycznej, gdzie zapowiedziano rozwój badań nad alternatywnymi źródłami energii. Wzrost zapotrzebowania państw europejskich na energię, wahania cen na międzynarodowym rynku oraz niestabilna sytuacja polityczna u głównych dostawców Europy, szczególnie Rosji, tylko wzmocnily przekonanie, że alternatywne sposoby zapewnienia energii w Europie powinny być rozwijane (Doğușhan Kara, 2014, s. 3).

W Białej Księdze - Energia dla przyszłości - odnawialne źródła energii z 1997 roku oraz Zielonej Księdze - O bezpieczeństwie energetycznym z 2000 roku, Unia Europejska zidentyfikowała najważniejsze wyznania i wytyczne w zakresie rozwoju OZE. W 2001, 2002 i 2003 roku Komisja Europejska wydała dyrektywy w sprawie wspierania produkcji energii elektrycznej na rynku wewnętrznym wytwarzanej ze źródeł odnawialnych, efektywności energetycznej, promocji OZE oraz ograniczenia emisji zanieczyszczeń do atmosfery (Dyrektywa 2001/77/WE; Dyrektywa 2001/80/WE; Dyrektywa 2002/90/WE; Dyrektywa 2003/30/WE). Mapa drogowa na rzecz energii odnawialnej - Energia odnawialna w XXI wieku: budowa bardziej zrównoważonej przyszłości z 2007 (Komisja Europejska, 2007), Strategia na rzecz konkurencyjnego, zrównoważonego i bezpiecznego sektora energetycznego z 2010 roku (Komisja Europejska, 2010), dokument Ramy polityczne na okres 2020-2030 dotyczace klimatu i energii z 2014 roku (Komisja Europejska, 2014), Plan działania w zakresie energii do 2050 roku (Komisja Europejska, 2011), określają najważniejsze wyzwania, którym Unia i państwa członkowskie powinny sprostać w obszarze energii, w tym wskazują konkretne cele w zakresie rozwoju i wykorzystania OZE oraz warunki rozbudowy połączeń transmisji energii elektrycznej pomiędzy państwami UE. Do roku 2020 Unia planuje zwiększenie udziału energii odnawialnej w bilansie energetycznym UE, o co-

1 Odnawialne źródła energii - OZE - „dotyczą każdego źródła energii, które w naturalny sposób regeneruje się w krótkim czasie i pochodzi bezpośrednio od słońca (np. źródla termiczne, fotochemiczne i fotoelektryczne), pośrednio od słońca (takie jak wiatr, energia wodna, energia biomasy) lub $\mathrm{z}$ innych naturalnych mechanizmów środowiska (energia geotermalna i energia plywów morskich). Odnawialne źródła energii powinny być również definiowane jako źródla wytwarzania energii elektrycznej" (Doğuşhan Kara, 2014). 
najmniej $20 \%$, ponadto $10 \%$ paliw zużywanych w transporcie mają stanowić biopaliwa, poprawę efektywności energetycznej o co najmniej $20 \%$ oraz zmniejszenie emisji gazów cieplarniach o 20\%, w porównaniu do poziomu z 1990 roku, mając na celu przekształcenie Europy w energooszczędną i niskoemisyjną gospodarkę. Do 2030 roku ze źródeł odnawialnych pochodzić ma obowiązkowo $27 \%$ energii zużywanej w Europie, redukcja emisji gazów cieplarnianych ma zmniejszyć się o co najmniej $40 \%$ w porównaniu do 1990 roku, a w roku 2050 o 80-90\%. Bezpośrednio do odnawialnych źródeł energii odnosi się również art. 194 Traktatu o funkcjonowaniu Unii Europejskiej: ,polityka energetyczna UE ma na celu wspieranie rozwoju nowych i odnawialnych form energii” (Kerebel, 2015). Również Europejska strategia bezpieczeństwa energetycznego, wskazuje na konieczność zwiększenia krajowej produkcji energii, w tym rozwoju odnawialnych źródeł energii. Cele UE w zakresie energii i zmiany klimatu zostały włączone także do strategii Europa 2020 na rzecz inteligentnego i zrównoważonego rozwoju sprzyjajacego właczeniu spolecznemu przyjętej przez Radę Europejską w czerwcu 2010 roku. Wytyczne dla państw członkowskich w zakresie osiagnięcia celów do 2020 roku oraz mechanizmy współpracy pomiędzy państwami członkowskimi w zakresie odnawialnych źródel określa Dyrektywa Parlamentu Europejskiego i Rady w sprawie promowania stosowania energii ze źródel odnawialnych uchylajaca dyrektywy 2001/77/WE oraz 2003/30/WE z 2009 roku (Parlament Europejski, 2009). W 2010 roku dla każdego państwa członkowskiego zostały przygotowane plany działania określające krajowe cele w zakresie energii odnawialnej i efektywności energetycznej, poddane ewaluacji i ocenie w 2011 i 2013 roku (Hedberg, 2015, s. 1-4).

Unia Europejska w ciągu ostatnich lat stała się pionierem w obszarze odnawialnych źródel energii: ponad 40\% światowej mocy elektrycznej pochodzącej ze źródel odnawialnych (nie licząc elektrowni wodnych) wytwarzane jest w Europie. W sektorze tym zatrudnionych jest ponad milion pracowników. W 2012 roku według badań Eurostatu prawie 15\% energii w Unii Europejskiej pochodziło ze źródeł odnawialnych, co stanowiło wzrost o ponad 13\% w porównaniu do roku 2011. Energia wodna jest najważniejszym odnawialnym źródłem energii elektrycznej i generuje $46 \%$ produkcji energii elektrycznej ze źródeł odnawialnych w UE, wiatrowa $26 \%$, biomasa $19 \%$ oraz słoneczna 8\% (Komisja Europejska, 2014a, s. 82).

\section{Sytuacja energetyczna w państwach śródziemnomorskich}

Państwa śródziemnomorskie różnią się sytuacją energetyczną. Algieria i Libia mają dużą bazę zasobów naturalnych i są ich eksporterami. Algieria zajmuje 16 miejsce w światowych rezerwach ropy naftowej, ma ósme największe rezerwy gazu ziemnego na świecie, i jest czwartym, co do wielkości eksporterem gazu. Gospodarka Algierii w dużym stopniu opiera się na sprzedaży gazu, z której pochodzi około $60 \%$ dochodów, $30 \%$ PKB i ponad 95\% eksportu. Podobnie gospodarka Libii zależy w dużej mierze od przychodów z sektora naftowego, generującego około 95\% eksportu, 25\% PKB i 75\% dochodów budżetowych (Dzisiów-Szuszczykiewicz, 2012, s. 137). Egipt eksportuje gaz ziemny, natomiast jest importerem ropy naftowej. Większość państw śródziemnomorskich jest jednak zależna od zewnętrznych dostaw. Tunezja importuje $25 \%$ su- 
rowców energetycznych, Maroko dorównuje Jordanii i jest zależne w ponad $90 \%$ od eksportu ropy i gazu. Importerami surowców są także Liban oraz Autonomia Palestyńska. Warto zaznaczyć, iż Maroko posiada 15\% rezerw światowych ropy naftowej w łupkach, jednak ze względu na wysokie koszty jej wydobycia nie jest wydobywana (Weissenbacher, 2012a, s. 455-457). W Jordanii koszty importu paliw kopalnych, pochłaniają około 20\% PKB (The Future, 2013, s. 7). Warto zwrócić uwagę, iż przykładowo Tunezja i Maroko, tylko w niewielkim stopniu korzystają ze źródeł sąsiadów, ze względu na niski poziom współpracy regionalnej i skomplikowaną sytuację polityczną w regionie (Kilpeläinen, 2013, s. 351).

To co jest wspólne dla państw regionu to szybki wzrost konsumpcji energetycznej, która związana jest $\mathrm{z}$ boomem demograficznym oraz transformacją gospodarczą. Jak podkreślają specjaliści, zależność między dostępem do energii a rozwojem jest szczególnie silna na etapie modernizacji gospodarki, z którą mamy do czynienia obecnie w regionie śródziemnomorskim, obecnie podążającym klasyczną drogą industrializacji, gdzie gospodarka opiera się głównie na produkcji (Bergasse, 2013, s. 2-15). Szacunki wskazują, iż liczba ludności w obszarze MENA wzrośnie do około $395 \mathrm{mln}$ w 2030 roku i do $426 \mathrm{mln}$ w roku 2050 tym samym zwiększy się zapotrzebowanie na energię. Tylko w latach 2001-2011, zużycie energii elektrycznej na mieszkańca w Afryce Północnej wzrosło o ponad 50\% i było wyższe niż średnia światowa, biorąc pod uwage gospodarki o średnich dochodach (Weissenbacher, 2012b, s. 235-239). W 2013 roku MEDREG wskazał, iż popyt na energię w regionie MENA będzie rosnąć 3\% rocznie pomiędzy rokiem 2010-2030 (MEDREG, 2013b, s. 12). Ponadto większe zużycie energii ma wpływ na klimat i zanieczyszczenie środowiska. Poziom emisji gazów cieplarnianych w latach 2001-2010 w Afryce Północnej zwiększył się o 50\%, zdecydowanie przewyższając średnią światową. Państwa regionu borykają się również z problemem braku dostępu do słodkiej wody, a technologie jej odsalania są drogie i wymagają wysokich nakładów energetycznych (Hong, 2014, s. 236). Hafner i Tagliapietra podkreślają, iż region cechuje niska efektywność energetyczna, związana m.in. $\mathrm{z}$ dotacjami rządowymi do podstawowych produktów energetycznych. W wymiarze gospodarczym dotacje negatywnie wpływają na potencjał inwestycyjny poszczególnych państw i na bardziej racjonalną, oszczędną i efektywną politykę energetyczną (Hafner, Tagliapietra, 2013, s. 1-6). Ceny energii we wszystkich państwach utrzymywane są sztucznie na niskim poziomie. Międzynarodowa Agencja Energii (IEA) w 2014 roku wskazała, iż dotacje do paliw w Algierii i Egipcie wynoszą ponad 50\%, a ceny na stacjach benzynowych w tych państwach są niższe o $10 \%$ niż na świecie (Hong, 2014, s. 233).

W związku z powyższym państwa śródziemnomorskie, zarówno eksporterzy jak i importerzy energii, narażone są na wahania cen energii na międzynarodowych rynkach. Jak podkreślają Colombo i Sartori, dla państw śródziemnomorskich będących na drodze zmian i poszukiwania adekwatnej drogi rozwoju, bezpieczeństwo energetyczne jest kluczową sprawą ściśle sprzężoną z szerszymi warunkami społeczno-ekonomicznymi jest powiązane z rozwojem oraz funkcjonowaniem wszystkich sektorów gospodarki (Colombo, Sartori, 2014, s. 7-10). Warto dodać, iż sytuacja energetyczna odegrała istotna, choć pośrednią rolę w arabskich powstaniach w 2011 roku. Wcześniej w latach 2007-2011 ceny paliw oraz energii elektrycznej na międzynarodowym rynku wzrosły, 
co w efekcie miało wpływ na wysokie ceny podstawowych produktów i pogorszenie sytuacji gospodarczej, szczególnie w Tunezji.

Dużą szansą dla tych państw, aby sprostać wyzwaniom rozwojowym jest pozyskanie energii elektrycznej ze źródeł odnawialnych. Jak podkreślają specjaliści energia odnawialna odgrywa zasadniczą rolę w procesie przechodzenia w kierunku bardziej konkurencyjnego, bezpiecznego i zrównoważonego systemu energetycznego. W państwach eksportujących surowce naturalne, OZE przyczynią się do ograniczenia krajowego zużycia ropy i gazu oraz większych możliwości eksportowych. Dla importerów energii wykorzystanie OZE do produkcji energii elektrycznej zmniejszy obciążenia budżetowe (IRENA, REN21, MOFA, 2013, s. 6). Według analizy przygotowanej przez niemiecki koncern DLR (German Aerospace Center) potencjał regionu śródziemnomorskiego w zakresie skoncentrowanej energii słonecznej (CSP) wynosi 431,382 TWh/y i jest zdecydowanie większy (o 300 razy) niż w północnych państwach Unii Europejskiej - badanie to wyklucza tereny, które nie nadają się na instalację systemów solarnych. W zakresie potencjału energii elektrycznej wytwarzanej z promieniowania słonecznego przy wykorzystaniu fotowoltaiki (system PV), raport podaje, iż potencjał państw wschodniego i południowego Śródziemnomorza wynosi $122 \mathrm{TWh} / \mathrm{y}$ a w północnych państwach Unii jedynie $22 \mathrm{TWh} / \mathrm{y}$. W odniesieniu do energii wiatrowej potencjał regionu śródziemnomorskiego szacuje się na $21,967 \mathrm{TWh} / \mathrm{y}$ a na północy na $648 \mathrm{TWh} / \mathrm{y}$. Raport podkreśla jednak, iż w przypadku energii wiatrowej na $1 \mathrm{~km}^{2}$ można zainstalować urządzenia generujące jedynie $10 \mathrm{MW}$ (Tagliapietra, 2015, s. 17-24).

Zwiększenie wykorzystania źródeł energii elektrycznej z OZE jest jednym z głównych elementów modernizacji energetycznej oraz modernizacji gospodarczej w państwach śródziemnomorskich. Przewiduje się, iż rozwój energii odnawialnej przyczyni się do poprawy warunków społeczno-gospodarczych w tym do eliminacji ubóstwa energetycznego, do redukcji emisji gazów cieplarnianych, poprawy funkcjonowania służby zdrowia, usług sanitarnych, budowy mieszkań, lepszej komunikacji i większych możliwości odsalania wody. Programy infrastrukturalne pobudzą nowe inwestycje w sektorach pośrednich, w szczególności elektronikę, telekomunikację i informatykę oraz mogą być skutecznym narzędziem walki z bezrobociem poprzez generowanie nowych miejsc pracy w sektorze OZE (FEMISE, 2012, s. 88-107). W 2008 roku Program Środowiskowy ONZ (UNEP) i Międzynarodowa Organizacja Pracy (ILO) oszacowały, iż energia PV może wytworzyć o 7 miejsc pracy więcej niż elektrownie węglowe i dwa razy więcej niż te wykorzystujące gaz - biorąc pod uwage wytworzenie tej samej energii (MW/h) w tym samym czasie. W 2015 roku Międzynarodowa Agencja Energii Odnawialnej wskazała na $18 \%$ wzrost zatrudnienia do 7,7 mln osób w sektorze OZE w 2014 roku w stosunku do 2013 roku (IRENA, 2015, s. 2). Badanie Banku Światowego z 2011 roku wskazało, iż sektor OZE w państwach MENA wytworzy 180 tys. miejsc pracy do 2025 roku, tylko w obszarze CSP (Tagliapietra, 2015, s. 25-26). Rozwój energetyki odnawialnej powiązany jest również $\mathrm{z}$ inwestycjami w edukację $\mathrm{i}$ badania. W ostatnich latach wydatki publiczne na edukację w większości państw śródziemnomorskich, znacznie wzrosły. Hong podkreśla, iż w Maroku edukacja pochłania 25\% wydatków publicznych, a w ciągu ostatniej dekady inwestycje w badania i rozwój zwiększyły się o 47\% w Egipcie i 18\% w Maroku, a liczba naukowców tylko w Afryce Północnej wzrosła o około 35\% (Hong, 2014, s. 237-240). 
W regionie MENA około 20 milionów ludzi zwłaszcza w odległych i słabo zaludnionych obszarach wiejskich, nie ma dostępu do energii elektrycznej niezbędnej do zaspokojenia podstawowych potrzeb w tym $1 \mathrm{mln}$ Marokańczyków i 1,4 mln Syryjczyków. W 2013 roku Organizacja Współpracy Gospodarczej i Rozwoju (OECD) podkreśliła, iż rozwój nawet niewielkich instalacji do pozyskania energii wiatrowej i słonecznej na obszarach wiejskich może znacznie przyczynić się do wzrostu poziomu życia mieszkańców. Dostęp do oświetlenia pozwoli na dłuższą pracę w lepszych warunkach. Powstaną małe przedsiębiorstwa zajmujące się obsługą logistyczną i konserwacją urządzeń oraz narzędzi niezbędnych do zainstalowania odpowiedniej infrastruktury, co zmniejszy bezrobocie. Ponadto wiele gospodarstw domowych w państwach śródziemnomorskich wykorzystuje nadal biomasę do gotowania i ogrzewania, co ma negatywny wpływ na zdrowie, środowisko i jest bardziej pracochłonne (IRENA, REN21, MOFA, 2013, s. 7). Dlatego też wykorzystanie OZE do produkcji energii elektrycznej na obszarach wiejskich będzie miało, nieoceniony wpływ na sytuację kobiet odpowiedzialnych za prowadzenie gospodarstw domowych (Tagliapietra, 2015, s. 27).

W latach 2008-2011 produkcja energii odnawialnej w państwach śródziemnomorskich zwiększyła się dwukrotnie. Najszybciej w regionie rozwija się energetyka wiatrowa, która ma stać się głównym źródłem energii odnawialnej po energii wodnej, zwłaszcza w Egipcie, Maroku i Tunezji. Zdecydowanie wolniej rozwija się sektor energii słonecznej, chociaż badania wskazują na duży jego potencjał ze względu na malejące koszty technologii. Od 2008 do 2011 roku, produkcja energii ze źródeł PV wzrastała rocznie o ponad $100 \%$ i była głównie wykorzystywana w programach elektryfikacji obszarów wiejskich. Pionierem jest w tym obszarze Maroko, które od 1997 roku wdraża projekt elektryfikacji wsi (PERG) w oparciu o mini sieci napędzane przez wiatr i energię słoneczna, z którego skorzystało ponad $1 \mathrm{mln}$ gospodarstw domowych. Najmniej popularna w regionie jest energia geotermalna, która wykorzystywana jest w Autonomii Palestyńskiej, plany w tym obszarze z państw śródziemnomorskich posiada również Algieria. Systemy nagrzewania wody (SWH) są również kluczowe we wdrażaniu odnawialnych źródeł energii w regionie. Dominującą pozycję zajmują tutaj Tunezja, wdrażając program PROSOL oraz Maroko realizujące program PROMASOL (IRENA, REN21, MOFA, 2013, s. 6-30).

W ostatnich latach nastapił rozwój regionalnych instytucji zajmujących się promocją wykorzystania OZE, transferem dobrych praktyk, badaniami potencjału poszczególnych państw, kreowaniem norm, zasad i reguł regionalnej polityki w tym obszarze oraz finansowaniem projektów OZE w regionie MENA. Wśród najważniejszych można wymienić powstałe w 2008 roku w Kairze, Regionalne Centrum Energii Odnawialnej i Efektywności Energetycznej (RCREEE). RCREEE jest niezależną organizacją non-profit, której celem jest promocja efektywności energetycznej i wymiana dobrych praktyk w tym zakresie. Obecnie skupia 16 państw arabskich oraz Autonomię Palestyńską. Centrum współpracuje z państwami, przedsiębiorstwami, organizacjami międzynarodowymi, jest zaangażowane we wdrażanie projektów lokalnych i regionalnych. RCREEE jest finansowana ze składek państw członkowskich, dotacji od Niemieckiej Agencji Rozwoju (GIZ), od Danii za pośrednictwem Duńskiej Agencji Rozwoju (Danida) oraz od Egiptu poprzez Nowy Urząd Energii Odnawialnej (NREA) (RCREEE, 2015a). Sektor energii odnawialnej zajmuje ważne miejsce na agendzie Ligi Państw 
Arabskich, która przyjęła Strategię Rozwoju Energii Odnawialnej oraz dyrektywę dotyczącą efektywności energetycznej na lata 2011-2012, a w 2013 roku uruchomiła nowy projekt na lata 2015-2020 w zakresie budowania pan-arabskiej strategii rozwoju energii odnawialnej do 2030 roku (Varouxakis, 2013, s. 264). Ze względu na potencjał wytwarzania energii odnawialnej państwa regionu śródziemnomorskiego stały się miejscem zainteresowania globalnych graczy energetycznych. W projekty energetyczne zaangażowane są firmy z Arabii Saudyjskiej, Zjednoczonych Emiratów Arabskich, Francji, Niemiec, Japonii oraz międzynarodowe instytucje finansowe i banki m.in. niemiecki KfW, Bank Światowy, ONZ, Afrykański Bank Rozwoju oraz fundusze regionalne, wśród których dużą aktywność wykazuje Fundusz Rozwoju z Abu Dhabi. Nowe inwestycje w odnawialne źródła energii w regionie wyniosły 2,9 mld dolarów w 2012 roku, co stanowi wzrost o prawie $40 \%$ w stosunku do 2011 roku i ponad 6-krotny porównując z 2004 rokiem (IRENA, REN21, MOFA, 2013, s. 10-28).

Nastawienie poszczególnych państw śródziemnomorskich do programów rozwoju odnawialnych źródeł energii jest bardzo zmienne i zależy od kontekstu politycznego oraz od naturalnych zasobów energetycznych, chociaż wszystkie posiadają narodowe plany i cele rozwoju energii odnawialnej oraz zwiększenia efektywności energetycznej. Algierski plan opracowany przez Ministerstwo Energetyki i Górnictwa zakłada osiągnięcie w 2030 roku 40\% krajowego zużycia energii elektrycznej z OZE. Część wytworzonej energii ma być również przeznaczona na eksport. Głównie ma pochodzić $\mathrm{z}$ energii słonecznej, plan zwraca również uwagę na potencjał wiatru, biomasy, energii geotermalnej i wodnej. W Algierii dwie główne instytucje odpowiedzialne są za politykę państwa w tym obszarze: Narodowa Agencja Promocji i Racjonalizacji Zużycia Energii (APRUE) oraz instytucja promująca nowe źródła energii (NEAL) (RCREEE, 2012a). Plany Autonomii Palestyńskiej w zakresie OZE mają na celu osiągnięcie 10\% krajowej produkcji energii elektrycznej z OZE do 2020 roku. W 2012 roku została przyjęta strategia dotycząca efektywności energetycznej. Agencja Energii (PEA), Palestyńskie Centrum Badań nad Energią i Środowiskiem, Rada Regulacyjna Energii Elektrycznej są głównymi organami odpowiedzialnymi za promowanie i wspieranie OZE na terenach Autonomii Palestyńskiej (RCREEE, 2012g).

Strategia energetyczna Egiptu z 2007 roku wskazuje na cel pozyskania $20 \%$ energii ze źródeł odnawialnych do 2020 roku, 12\% pochodzić ma z elektrowni wiatrowych, $5,8 \% \mathrm{z}$ elektrowni wodnych i $2,2 \% \mathrm{z}$ innych źródeł odnawialnych, w szczególności energii słonecznej. Egipt przyjął również krajowy plan działania dotyczący efektywności energetycznej na lata 2012-2015. W Egipcie agencja NREA odpowiedzialna jest za promowanie i wspieranie rozwoju alternatywnych źródeł energii. Egipt przygotował dwa atlasy wiatru identyfikujące najlepsze tereny dla instalacji do pozyskania energii, znajdują się one na obszarze Zatoki Sueskiej oraz w regionie Zatoka el Zayt i na obszarach Wschodniego i Zachodniego Nilu. Rząd Jordanii planuje pozyskanie $10 \%$ energii ze źródeł odnawialnych do 2020 roku oraz zwiększenie efektywności energetycznej o 20\% do 2020 roku. W Jordanii Ministerstwo Energetyki i Zasobów Mineralnych ustanowiło specjalny Fundusz Efektywności Energetycznej oraz Energii Odnawialnej (JREEEF) odpowiedzialny za promowanie OZE. W 2007 roku Jordania opublikowała mapę wiatrową oraz atlas słoneczny, według których obszary na południu i wschodzie państwa zostały uznane jako najlepsze dla instalacji wiatrowych i słonecznych 
(RCREEE, 2012b-c). Cele Libanu w zakresie OZE zakładają osiagniecie 12\% energii ze źródeł odnawialnych do 2030 roku. Krajowy Plan Działań dotyczący efektywności energetycznej (EEAP) na lata 2011-2015 został przyjęty w listopadzie 2011 roku. Wszystkie działania związane ze wspieraniem i promowaniem OZE w Libanie objęte sa patronatem Centrum Poszanowania Energii Libanu (LCEC). Liban opublikował szczegółowy atlas wiatru, najlepsze tereny znajdują się na północy państwa i przy wschodniej granicy z Syria. W Libii Agencja Energii Odnawialnej (REAOL), utworzona w 2007 roku, zapowiedziała, iż w 2025 roku państwo osiagnie 10\% energii elektrycznej z OZE. Libia jest $\mathrm{w}$ procesie przygotowania narodowego planu działania dotyczącego efektywności energetycznej (EEAP). Według libijskiego atlasu określającego miejsca nadające się do instalacji wiatrowej, największy potencjał posiadaja regiony: Darnah i Al-Magron. Narodowy plan Maroka, państwa najbardziej zaawansowanego w wykorzystaniu OZE, zakłada osiagnięcie $42 \%$ energii elektrycznej ze źródeł odnawialnych do roku 2020. Największy udział ma mieć energia słoneczna. W tym celu od 2009 Maroko wdraża plan słoneczny pod patronatem Marokańskiej Agencji Energetyki Słonecznej (MASEN). Realizacja planu wspierana jest przez niemiecką agencję GIZ, która jest zaangażowana w rozwój energii słonecznej w Maroku od 1975 roku (GIZ, 2013, s. 1). Agencja Rozwoju Energii Odnawialnej i Efektywności Energetycznej (ADEREE) jest odpowiedzialna za promowanie efektywności energetycznej oraz OZE. Fundusz Rozwoju Energii (FDE) założony w 2010 roku finansuje projekty pozyskania energii ze źródeł odnawialnych i efektywności energetycznej. Maroko przygotowało również szczegółowy atlas wiatrowy i słoneczny. Obszary zidentyfikowane jako najlepsze do wdrażania projektów słonecznych to: Ouarzazate, Ain Beni Mathar, Foum Al Ouad Al-Ujun, Boujdour, a Sebkhat Tah/Tarfaya. W Syrii rząd postawił sobie za cel zaspokojenia $10 \%$ zapotrzebowania na energię z odnawialnych źródeł energii do $2020 \mathrm{roku}$ (RCREEE, 2012f-h). W Tunezji plan rządowy zakłada osiagnięcie $30 \%$ produkcji energii elektrycznej z odnawialnych źródeł energii do 2030 roku, głównie ma być pozyskana z wiatru. Wszystkie działania związane ze wspieraniem i promowaniem OZE w Tunezji prowadzone są pod patronatem Ministerstwa Przemystu i Technologii. Narodowa Agencja Poszanowania Energii (ANME) jest odpowiedzialna za formułowanie, promowanie i wdrażanie wytycznych w zakresie efektywności energetycznej. Funkcjonuje również Narodowy Fundusz Oszczędności Energii (FNME) udzielający dofinansowania dla projektów w tym zakresie. ANME przygotowała szczegółowy atlas dotyczący najlepszych terenów na instalacje infrastruktury dla wytwarzania energii wiatrowej (RCREEE, 2012i).

W 2014 roku w panstwach arabskich ${ }^{2}$ udział zainstalowanej mocy OZE w całości sektora energetycznego wynosił $5,22 \%$ - w tym hydroinstalacje stanowiły $4,25 \%$, słoneczne $0,15 \%$, wiatrowe $0,79 \%$ i inne $0,02 \%$ (RCREEE, 2015b, s. 36). Z państw śródziemnomorskich najlepiej radzi sobie Maroko, gdzie udział OZE wynosił w 2014 roku $35,4 \%$ (z czego prawie $25 \%$ to hydroinstalacje a nieco ponad $10 \%$ solarne) najgorzej wypada Libia i Autonomia Palestyńska, gdzie udział zainstalowanej mocy OZE

2 Badanie RCREEE uwzględnialo 16 państw arabskich, Algierię, Arabię Saudyjską, Bahrajn, Dżibuti, Egipt, Irak, Kuwejt, Jemen, Jordanię, Liban, Libię, Maroko, Mauretanię, Syrię, Tunezję. ZEA oraz Autonomię Palestyńska. 
W całości infrastruktury energetycznej wynosił 1\%. W Jordanii i Tunezji niecałe 5\% w Algierii około 7\%, w Libanie 8\%, w Egipcie i Syrii około 10\% (RCREEE, 2015c, s. 83). Warto zauważyć, iż w skali całego regionu śródziemnomorskiego wykorzystanie OZE jest niższe iż w UE, pomimo większego potencjału pozyskania energii ze źródeł odnawialnych.

\section{Projekty eurośródziemnomorskie}

Rozwój eurośródziemnomorskich projektów energetycznych w tym w szczególności w sektorze OZE, ściśle związany jest wewnętrznymi celami Unii w zakresie bezpieczeństwa energetycznego i dywersyfikacji źródeł dostaw. We wspominanej wyżej dyrektywie z 2009 roku Komisja wskazała, iż potencjalne trudności w osiagnięciu celów OZE przez poszczególne państwa mogą być przezwyciężone poprzez współpracę i transfer energii elektrycznej ze źródeł odnawialnych z państw zewnętrznych (FEMISE, 2012, s. 32-36).

W ramach Europejskiej Polityki Sąsiedztwa i Partnerstwa Eurośródziemnomorskiego, Unii dla Śródziemnomorza, Unia Europejska rozwinęła kilka kanałów współpracy w obszarze energii. Kwestie dotyczące energii dyskutowane są podczas spotkań ministrów do spraw energii oraz w ramach Euro-Med Forum Energetyczne, które funkcjonuje od 1996 roku. Działalność forum skupia się na promowaniu bezpieczeństwa dostaw, projektów ochrony środowiska naturalnego i wzrostu gospodarczego. W 2003 roku Komisja Europejska zaproponowała utworzenie Eurośródziemnomorskiego partnerstwa energetycznego w celu stopniowej integracji rynków energii elektrycznej i gazu, zwiększenia bezpieczeństwa dostaw energii, rozwoju infrastruktury niezbędnej do transport ropy naftowej, wzmocnienia połączeń energetycznych oraz rozwój współpracy w zakresie odnawialnych źródeł energii (Komisja Europejska, 2003). Kompleksowa strategia współpracy energetycznej Unii z państwami śródziemnomorskimi została przedstawiona $w$ regionalnym planie działania na lata 2008-2013 przyjętym w grudniu 2007 roku na konferencji w Limassol na Cyprze. Unia Europejska zaproponowała szeroki zestaw pomocy technicznej i finansowej dla regionalnych projektów energetycznych w tym dotyczących rozwoju infrastruktury energetycznej oraz rozwój współpracy badawczej w zakresie odnawialnych źródeł energii (Council of the European Union, 2007).

W odpowiedzi na wydarzenia Arabskiej Wiosny w komunikacie Komisji i Wysokiego Przedstawiciela Partnerstwo na rzecz demokracji i wspólnego dobrobytu z południowym regionem Morza Śródziemnego z 8 marca 2011 roku oraz dokumencie reformującym Europejską Politykę Sąsiedztwa z 25 maja 2011 roku, Komisja wskazała na perspektywy integracji południowego regionu Morza Śródziemnego do wewnętrznego rynku energii UE. Celem stało się utworzenie wspólnoty energetycznej państw Morza Śródziemnego oraz kształtowanie wspólnego podejścia do bezpieczeństwa energetycznego. Komisja podkreśliła konieczność zwiększenia produkcji energii ze źródel odnawialnych i mechanizmów zarządzania tym sektorem, w szczególności energii słonecznej i wiatrowej (European Commission, 2011a-b). W listopadzie 2011 roku zaproponowano utworzenie eurośródziemnomorskiego partnerstwa energetycz- 
nego, gdzie odnawialne źródła energii zajmują priorytetowe miejsce w produkcji energii elektrycznej (European Commission, 2011c). Podkreślono strategiczne znaczenie południowych sąsiadów w zakresie dostaw i tranzytu energii do Europy oraz konieczność zaangażowania Europy w reformy rynku w tym obszarze. José Manuel Barroso - przewodniczący Komisji Europejskiej wskazał, iż energia jest priorytetową dziedziną współpracy eurośródziemnomorskiej i jest kluczową częścią procesu budowy wspólnej przestrzeni stabilności i rozwoju (ENPI, 2013, s. 3).

Maroko i Algieria są najbardziej zawansowane we współpracy energetycznej z Unią. W 2007 roku Maroko podpisało deklarację w sprawie priorytetów współpracy energetycznej (FEMISE, 2012, s. 6). Maroko dominuje w sektorze OZE, Algieria z uwagi na posiadane surowce naturalne. W 2013 roku ustanowiono strategiczne partnerstwo energetyczne z Algierią. W maju 2015 roku rozpoczęty został dialogu polityczny z Algierią w kwestiach energetycznych, który ma obejmować współprace w zakresie gazu ziemnego, energii odnawialnej, efektywności energetycznej integracji regionalnej i budowy połączeń infrastrukturalnych. Planuje się utworzenie specjalnego forum biznesu w sprawach energii, pierwsze spotkanie zaplanowano na 2016 rok w Algierze. UE zgodziła się udostępnić swoją wiedzę doświadczenie i technologie, w celu sprostania wyzwaniom Algierii w obszarze energii i efektywności energetycznej (European Commission, 2015).

UE poprzez fundusze programów śródziemnomorskich głównie Europejskiego Instrumentu Sąsiedztwa (ENI - wcześniej w latach 2007-2013 ENPI), finansuje wiele projektów wspierających sektor energii w państwach śródziemnomorskich. Mają one charakter inicjatyw regionalnych, jak i bezpośrednio kierowane są do poszczególnych państw śródziemnomorskich. Do najważniejszych należą: projekt MED-ENEC - Energy Efficiency in Construction wdrażany w dwóch fazach 2006-2009 oraz 2009-2013 o budżecie $5 \mathrm{mln}$ euro (II faza), skierowany do Algierii, Egiptu, Izraela, Jordanii, Libanu, Libii, Autonomii Palestyńskiej, Maroka, Syrii, Tunezji, Turcji. Projekt zapewnia wsparcie dla inicjatyw promujących efektywność energetyczną i wykorzystanie energii słonecznej w branży budowlanej. Kolejny to MED-REG - Energy Regulators realizowany w latach 2010-2013 i 2013-2016 przez: Algierię, Egipt, Izrael, Jordanię, Liban, Libię, Autonomię Palestyńską, Maroko, Syrię, Tunezję, zapewnia wsparcie dla przygotowania i wdrożenia odpowiednich ram regulacyjnych w zakresie reformy rynku energii (ENPI, 2013, s. 3). Algieria, Maroko i Tunezja realizują projekt stopniowej integracji rynków energii elektrycznej do wewnętrznego rynku energii w Unii Europejskiej. Głównym celem jest ujednolicenie ram prawnych i regulacyjnych oraz struktury przemysłowej w celu tworzenia wspólnego rynku energii elektrycznej. W Egipcie Unia finansowo wspiera projekt budowy farmy wiatrowej w Wind Farm in Gulf of El Zayt (projekt finansuje Komisja Europejska, Europejski Bank Inwestycyjny i niemiecki bank KfW) oraz udziela pomocy finansowej na realizację marokańskiego planu słonecznego (Ouarzazate Solar Plant). Unia finansuje ponadto projekt FREEME, który ma na celu promocję energii odnawialnej i efektywności energetycznej w Maroku i Egipcie (ENPI, 2015).

Pośrednio do sektora energii i efektywności energetycznej odnoszą się projekty polityki sąsiedztwa promujące zrównoważony rozwój, udzielające państwom śródziemnomorskim wsparcia dla badań w obszarze zmian klimatycznych i ich wpływu na 
poszczególne sektory gospodarki. Na poziomie władz lokalnych Unia Europejska wspiera prowadzenie bardziej oszczędnej i zrównoważonej polityki energetycznej, optując za podpisaniem przez władze lokalne tzw. Porozumienia Burmistrzów - porozumienia władz lokalnych w celu promowania efektywności energetycznej. Marokańskie miasto Saléis jako pierwsze w regionie podpisało dokument (ENPI, 2013, s. 7).

Największym projektem realizowanym w ramach programów unijnych z zakresu energii odnawialnej jest śródziemnomorski plan słoneczny (MSP). MSP został uruchomiony na szczycie w Paryżu w lipcu 2008 roku jako jeden z priorytetowych projektów Unii dla Śódziemnomorza. Rolą MSP jest identyfikacja i stworzenie odpowiednich warunków polityczno-instytucjonalnych, społeczno-ekonomicznych i infrastrukturalnych do szybkiego rozwoju energii odnawialnej i większej efektywności energetycznej w regionie Morza Śródziemnego (ENPI, 2013, s. 8). Główne cele MSP to wdrożenie nowych instalacji pozyskiwania energii odnawialnej o mocy $20 \mathrm{GW}$ do 2020 roku, w tym osiągnięcie zdolności przesyłowej do Europy, jak i pomiędzy państwami śródziemnomorskimi, poprawa efektywności energetycznej, utworzenie nowych zielonych miejsc pracy i rozwój przemysłu energetycznego na obszarze Śródziemnomorza. W czerwcu 2009 roku na spotkaniu ministrów do spraw energii przyjęto dwa strategiczne dokumenty, pierwszy dotyczył współpracy technologicznej, drugi określał sposoby zarządzania projektami OZE (FEMISE, 2012, s. 32). W 2013 roku Sekretariat UdŚ opracował nowy plan działania dla MSP, który określa techniczne, finansowe i prawne środki niezbędne do rozwoju odnawialnych źródeł energii i efektywności energetycznej w regionie Morza Śródziemnego. Ponadto zaznaczono, iż rozwój energii odnawialnych powinien odpowiadać na społeczno-gospodarcze wyzwania i czynniki definiujące rozwój społeczny, zrównoważony rozwój, tworzenie miejsc pracy, walkę z ubóstwem i zmianami klimatu oraz transfer know-how (Varouxakis, 2013, s. 265-267). W latach 2010-2013 Komisja Europejska sfinansowała projekt Paving the Way for the Mediterranean Solar Plan zapewniający wsparcia realizacji Śródziemnomorskiego Planu Słonecznego.

Oprócz projektów finansowanych bezpośrednio ze środków polityki sąsiedztwa, dla państw śródziemnomorskich dostępne są fundusze Europejskiego Banku Inwestycyjnego w ramach specjalnej inicjatywy FEMIP - wsparcie dla eurośródziemnomorskich inwestycji i partnerstwa - powstałej w 2002 roku. Aktywność FEMIP w sektorze energii ma na celu finansowanie projektów zapewniających poprawę dostępu ludności lokalnej do energii, integracji rynków i dywersyfikację źródeł dostaw, w szczególności poprzez wykorzystanie odnawialnych źródeł energii. FEMIP odgrywa kluczową rolę w finansowaniu śródziemnomorskiego planu słonecznego. FEMIP wspiera projekty energetyczne poprzez udzielanie pożyczek, pomocy technicznej i prowadzenie badań. EBI przykładowo partycypuje w projekcie budowy farm wiatrowych w Egipcie i Maroku, w projektach budowy systemów solarnych w Maroku, Tunezji i Egipcie (EBI, 2014). EBI jest w trakcie przygotowywania nowego instrumentu finansowego dla państw śródziemnomorskich, ELENA-MED, który inspirowany jest na unijnym programie ELENA EU - wsparcie dla władz lokalnych w sektorze energetycznym. Program ten finansował będzie małe projekty w dziedzinie efektywności energetycznej i energii odnawialnej na obszarach miejskich. W ciagu 17 lat EBI zamierza przeznaczyć na inwestycje prawie $17 \mathrm{mld}$ dolarów. Pilotażowe projekty zostały zaplanowane 
w Maroku oraz w Autonomii Palestyńskiej, gdzie przygotowywany jest program inwestycyjny dla 76 szpitali (EBI, 2013, s. 12-28). Od 2008 roku funkcjonuje Sąsiedzki Fundusz Inwestycyjny (NIF), którego podstawowym celem jest udzielanie dotacji i pożyczek dla kluczowych projektów infrastrukturalnych w sektorach transportu, energii, środowiska oraz wspieranie rozwoju sektora prywatnego w państwach polityki sąsiedztwa. W latach 2007-2013 UE przeznaczyła w sumie $745 \mathrm{mln}$ na fundusz NIF, projekty energetyczne i w zakresie transportu pochłonęy 30\% środków (European Commission, 2014b, s. 57). Od 2012 roku ze środków NIF wdrażany jest program MSP-PPI - wspierający rozwój projektów OZE i efektywności energetycznej (ENPI, 2013, s. 6). W 2011 roku pojawiał się kolejny kanał finansowania projektów OZE poprzez Europejski Bank Odbudowy i Rozwoju (EBIR), który rozszerzył swój zasięg działania na region śródziemnomorski. W 2010 r. powstał instrument finansowy InfraMed Infrastructure, który udziela dotacji na projekty budowy infrastruktury w południowych i wschodnich państwach śródziemnomorskich, z priorytetem ich wykorzystania na projekty OZE (Bergasse, 2011, s. 10). Fundusz został stworzony przez Europejski Bank Inwestycyjny wspólnie z bankami z Egiptu, Włoch, Maroka, Francji (Cassa Depositi e Prestiti z Włoch, Caisse des Dépôts et de consignations z Francji, EFG Hermes z Egiptu, Caisse de et de Gestion Dépôts z Maroka). Warto dodać, iż fundusz jest 50\% udziałowcem w jordańskiej spółce JWPC - Jordan Wind Project Company, która buduje farmę wiatrową $w$ regionie Tafila - największą prywatnie finansowaną farmę wiatrową w Jordanii (InfraMed, 2015).

Równocześnie na przestrzeni ostatnich lat powstało wiele instytucji zajmujących się promocją OZE i współpracy eurośródziemnomorskiej zainicjowanych przez Unię lub przez państwa członkowskie. Wśród najważniejszych można wymienić powstałe w 2006 roku Stowarzyszanie Regulatorów Energetyki (MEDREG), którego działalność wspierana jest przez Komisję Europejską (Colombo, Sartori, 2014, s. 12). Jednym z obszarów zainteresowania i badań MEDREG jest wspieranie wytwarzania energii elektrycznej ze źródeł odnawialnych i projektów efektywności energetycznej w regionie Morza Śródziemnego (MEDREG, 2013a). W 2003 roku powstało stowarzyszenie promujące transśródziemnomorską współpracę w zakresie OZE (TREC). Zainicjowane zostało przez niemieckie stowarzyszenie klubu rzymskiego. W 2007 roku TREC przygotował Biała Księge, w której przedstawiono potencjał produkcji energii słonecznej w państwach śródziemnomorskich i możliwości jej transmisji do Europy. W 2009 roku TREC powołał Fundację Desertec, która zainicjowała projekt DII (Desertec Industry Initiative) w celu implementacji wytycznych zawartych w Biatej Księdze - planuje się, aby do 2050 roku wytworzona energia elektryczna w regionie śródziemnomorskim zaspokajała do 15\% potrzeb Europy (Bauer, Hanelt, 2011, s. 26). W 2012 Desertec opublikował raport Desert Power 2050, w którym podkreślono konieczność współdziałania pomiędzy państwami Unii Europejskiej i regionu śródziemnomorskiego w zakresie OZE. W 2010 roku z francuskiej inicjatywy powstał MEDGRID (ex-TRANSGREEN), konsorcjum skupiające operatorów systemów przesyłowych energii elektrycznej oraz inwestorów. Celem jest rozbudowa eurośródziemnomorskiej sieci energetycznej w tym zainstalowanie $\mathrm{w}$ regionie śródziemnomorskim infrastruktury do produkcji energii elektrycznej o zdolności wytwórczej $20 \mathrm{GW}$ z tego $5 \mathrm{GW}$ ma być przeznaczone na eksport do Europy (Darbochue, 2011, s. 195-201). 
W 2012 roku powstało Stowarzyszenie Śródziemnomorskich Operatorów Systemów Przesyłowych - Med-TSO opierające się na europejskim ENTSOE UE - sieci operatorów systemów przesyłowych. Celem stowarzyszania jest promowanie integracji regionalnej w zakresie budowy rynku energii elektrycznej w tym w odniesieniu do zharmonizowania przepisów z zakresu zasad dostępu do sieci energetycznych i transmisji energii elektrycznej (ENPI, 2013, s. 4). Od 2012 roku działa również Platforma Dialogu Publiczno-Prywatnego w zakresie Energii - RES4Med. Platforma ma na celu promowanie wykorzystania odnawialnych źródeł energii w obszarze Morza Śródziemnego (Vigotti, 2013).

\section{Przeszkody w realizacji projektów OZE}

W badaniach nad potencjałem rozwoju energii odnawialnej w państwach śródziemnomorskich i współpracy z Europą w tym obszarze wskazuje się na kilka głównych problemów, które dotyczą kwestii gospodarczych i politycznych wpływających na poziom implementacji i prawdopodobieństwo realizacji zaplanowanych projektów (Kilpeläinen, 2013, s. 354-356). Państwa śródziemnomorskie są potencjalnie atrakcyjnym miejscem dla wdrażania projektów OZE, jednak tylko niewielka część ich możliwości została jak dotychczas wykorzystana. OECD w 2013 roku podkreśliła, iż konieczność budowy odpowiedniej infrastruktury, która pociaga za sobą wysokie nakłady finansowe, czyni ten sektor mniej konkurencyjnym w regionie. Ponadto pozyskanie energii z OZE nie odbywa się ciagle, zależne jest od pory dnia i czynników atmosferycznych, a jej magazynowanie jest kosztowne (Weissenbacher, 2012b, s. 235-239). Do tego wysoki poziom dotacji państwowych do energii konwencjonalnej negatywnie wpływa na ocenę opłacalności OZE. IEA podkreśla, iż ceny energii w regionie utrzymywane są sztucznie na niskim poziomie z powodów politycznych, a racjonalizacja ekonomiczna, nie poddaje się tutaj politycznym kalkulacjom (Tagliapietra, 2015, s. 44 47). El-Katiri wskazuje, iż spadające koszty technologii PV powodują, iż energia słoneczna jest już realną opcją dla wytwarzania energii elektrycznej, jeśli porównamy koszty wytworzenia energii elektrycznej tą technologią do cen na międzynarodowych rynkach. W 2012 roku Europejskie Stowarzyszenie Producentów Półprzewodników (ESIA), podało, iż przy cenach 80 dolarów za baryłkę ropy lub 13 dolarów za MMBtu gazu, wytworzenie energii elektrycznej z energii słonecznej staje się opłacalne. Inaczej sytuacja wygląda, jeśli porównamy koszty wytworzenia energii słonecznej do rzeczywistych cen w państwach śródziemnomorskich. Wszelkie oceny atrakcyjności i opłacalności wytworzenia energii słonecznej w tym regionie w dużej mierze zależą od tego, czy bierze się pod uwagę ceny na międzynarodowych rynkach czy też te subsydiowane przez rządy w państwach śródziemnomorskich (El-Katiri, 2014, s. 13).

Rozwój OZE hamuje również sytuacja polityczna w regionie. Państwa śródziemnomorskie nie są atrakcyjne dla zagranicznych inwestorów, obawiających się zainwestować swój kapitał w państwach o wysokim zagrożeniu eskalacji konfliktu. W rankingu Doing Business 2015 (World Bank, 2015) Maroko zajmuje dopiero 70 miejsce, a Libia znajduje się na 188, przedostatnim miejscu. Kilpeläinen, powołując się na badania przeprowadzone w 2008 roku, wskazuje na złożoność procedur biurokratycznych, ko- 
rupcję i niestabilność polityczną jako najważniejsze przeszkody dla inwestorów. Podkreśla, iż na skutek procesu zmian rozpoczętych w 2011 roku w regionie śródziemnomorskim, szczególnie w Egipcie i Libii, problemy te zostały wzmocnione (Kilpeläinen, 2013, s. 354-356).

Czynnikiem negatywnie wpływającym na rozwój projektów OZE niemal we wszystkich państwach śródziemnomorskich jest brak rozwiniętego sektora prywatnego i monopolizacja rynków energetycznych. Hong zwraca również uwagę na brak odpowiedniego potencjału kadrowego w regionie, wykwalifikowanych pracowników, szczególnie w zawodach technicznych. Przykładowo w Afryce Północnej większość absolwentów szkół wyższych wybiera humanistyczne kierunki studiów, preferując stabilną pracę w sektorze publicznym ze względu na standaryzację zarobków przez rząd (Hong, 2014, s. 245). W rankingu firmy doradczej Ernst \& Young, która publikuje od 2003 roku listę 40 najbardziej atrakcyjnych państw dla inwestycji w odnawialne źródła energii, znajdują się jedynie 2 państwa śródziemnomorskie (nie licząc Izraela i Turcji), Maroko na 27 pozycji oraz Egipt na 39 pozycji (Ernst \& Young, 2015).

W odniesieniu do współpracy z Europa, głównym problemem jest brak wspólnych ram regulacyjnych i słabo rozwinięta infrastruktura wewnątrz i na zewnątrz regionu oraz rosnące rozdrobnienie i zróżnicowanie społeczno-polityczne państw południowej i wschodniej części basenu Morza Śródziemnego, powodujące, iż perspektywy dla współpracy i integracji regionalnej nie są obiecujące. Każde z państw ma własne preferencje polityczne i cele w sektorze OZE i nie wszystkie dążą do ujednolicenia norm i przepisów tak jak tego oczekuje Europa. Również możliwość wpływu UE jest różna w poszczególnych państwach. Przykładowo Maroko, Tunezja i Jordania, są wysoko uzależnione ekonomicznie, politycznie i w zakresie bezpieczeństwa od UE i jej państw członkowskich. Rynek europejski jest głównym odbiorcą produktów wytwarzanych w tych państwach. Nie mają dostępu do znaczących zasobów naturalnych i potrzebują europejskiej pomocy rozwojowej. W znacznym stopniu ich rozwój jest uzależniony od wsparcia finansowego z UE i pomocy finansowej z poszczególnych państw członkowskich. Po drugiej stronie znajduje się Algieria i Egipt państwa o wyższym stopniu niezależności, posiadające zasoby naturalne, które powodują iż są one w znaczniej mierze, samowystarczalne ekonomicznie i niezależne od pomocy UE (Kausch, 2013, s. $25-40)$.

Kolejną sprawą jest sposób finansowania projektów OZE z instrumentów wsparcia UE dostępnych dla państw śródziemnomorskich. Jak wskazuje Bergasse finansowanie projektów w zakresie odnawialnych źródeł energii w perspektywie finansowej 2007-2013 nie stanowiło dużego udziału w środkach Unii Europejskiej w tym Europejskiego Banku Inwestycyjnego. Spośród łącznie prawie 10 mld euro pożyczek w okresie 2002-2009, sektor energii stanowil 37\%, z czego tylko $130 \mathrm{mln}$ euro $(1,3 \%)$ przeznaczono na projekty OZE. Sąsiedzki Fundusz Inwestycyjny: spośród $745 \mathrm{mln}$ euro przyznanych na lata 2007-2013, do 2011 roku sfinansował jedynie dwa projekty dotyczące energii słonecznej o wartości $11 \mathrm{mln}$ euro. Podkreśla, iż istniejący w UE system finansowania projektów energetycznych w regionie był dotychczas zróżnicowany, ale tym samym dość podzielony, niespójny i niejednorodny, przeznaczony w większości dla dużych inwestycji. Do tego główna inicjatywa MSP, promowana przez Unię ma opóźnienia w realizacji, nie wyszła poza sferę badań dotyczących ekonomicznej opłacalności pla- 
nowanych projektów, oceny możliwości technicznych i finansowych ich realizacji (Bergasse, 2011, s. 6-9). Tagliapietra wskazuje, iż w badaniach nad OZE we współpracy eurośródziemnomorskiej pojawia się ponadto wątpliwość czy mając swoje plany w zakresie rozwoju OZE, Europa potrzebuje państw śródziemnomorskich, biorąc pod uwagę wysokie koszty budowy planowanych połączeń energii elektrycznej i ich wysoki stopień skomplikowania i ryzyka, ze względu na konieczność usytuowania połączeń w głębokich wodach Morza Śródziemnego (Tagliapietra, 2015, s. 33).

Sektor energii zarówno w Unii Europejskiej, jak i w państwach śródziemnomorskich jest coraz bardziej zróżnicowany, szczególnie w kontekście zmieniającej się sytuacji międzynarodowej. Unia Europejska, ze względu na kryzys na Ukrainie i pogarszające się relacje z Rosją, głównym eksporterem energii, coraz bardziej nastawiona jest na dywersyfikację kanałów dostaw. $Z$ drugiej strony zmiany w południowej i wschodniej części Morza Śródziemnego rozpoczęte w 2011 roku na skutek protestów społeczno-politycznych wpłynęły na zmianę sytuacji wewnętrznej tych państw generując równocześnie nowe wyzwania społeczno-gospodarcze dla państw regionu oraz dla Europy, w tym w zakresie współpracy energetycznej. Dlatego też pomimo wskazania powyższych problemów w realizacji projektów OZE w regionie oraz w ramach programów eurośrdziemnomorskich, współpraca powinna być kontynuowana. Rozwój sektora odnawialnych źródeł energii w państwach śródziemnomorskich - nawet bez brania pod uwage jej transferu do państw UE - może generować pozytywne efekty pośrednie dla Europy związane m.in. ze zmniejszeniem migracji. Odnawialne źródła energii mogą stać się również bodźcem wzmocnionej współpracy eurośródziemnomorskiej w innych obszarach społeczno-ekonomicznych. Niewątpliwie realizacja planowanych inwestycji i projektów, będzie w dużym stopniu zależeć od dostępności finansowania i warunków politycznych, ale jest najbardziej obiecująca (Hafner, Tagliapietra, 2013, s. 2-6). Sektor OZE jest miejscem, w którym interesy polityczne i gospodarcze $\mathrm{w}$ tym interesy sektora prywatnego wydają się być komplementarne. $Z$ tego względu jest najbardziej perspektywicznym i dynamicznym obszarem współpracy eurośródziemnomorskiej.

\section{Bibliografia}

Aoun M. C. (2015), European Energy Security Challenges and Global Energy Trends: Old wine in new bottles, „IAI Working Papers”, nr 15, OCP Policy Center.

Bauer M., Hanelt Ch. P. (2011), The Arab World in Transition: Prospects and Challenges for a Revitalized Relationship between Europe and North Africa, Bertelsmann Stiftung Strategy Paper. Bertelsmann Stiftung and the Ministry of Foreign Affairs and Cooperation of the Kingdom of Morocco, Rabat, http://www.cap.lmu.de/download/2011/2011_Kronberg.pdf, 10.09.2013.

Bergasse E. (2011), Euromed energy cooperation \& the Mediterranean Solar Plan. A unique opportunity for a fresh start In a new era?, Documentos CIDOB Mediterraneoy Oriente Medio, nr 17.

Bergasse E. (2013), The relationship between energy and economic and social development in the southern Mediterranean, MEDPRO Technical Report, nr 27.

Brown P. (August 2013), European Union Wind and Solar Electricity Policies: Overview and Considerations, CRS Report for Congress, http://fas.org:8080/sgp/crs/row/R43176.pdf, 17.05.2015. 
Colombo S., Sartori N. (2014), Rethinking EU Energy Policies Towards the Southern Mediterranean Region, „IAI Working Papers”, nr 14.

Council of the European Union (2007), Ministerial Declaration on the Euro-Mediterranean Energy Partnership Adopted together with its annexes by Ministers at the conference in Limassol. 16709/07 (Presse 300), Cyprus.

Darbochue H. (2011), Third Time Lucky? Euro-Mediterranean Energy Co-operation under the Union for the Mediterranean, „Mediterranean Politics”, vol. 16, Issue 1.

Doğuşhan Kara M. (2014), Renewable energy in European Union: The Reveal of Development Plans for Environment, Institute for Energy Markets and Policies, Ankara.

Dzisiów-Szuszczykiewicz A. (2012), Dokad zmierza Libia bez Muammara Kaddafiego, „Krakowskie Studia Międzynarodowe", nr 1, Kraków.

EBI (2013), FEMIP Final report Energy Efficiency and Renewable Energy project preparation programme in urban areas of the Mediterranean Partner Countries, http://www.eib.org/attachments/country/femip_study_elena_en.pdf, 1.07.2015.

El-Katiri L. (2014), A Roadmap for Renewable Energy in the Middle East and North Africa, OIES PAPER: MEP 6, University of Oxford.

EBI (2014), FEMIP Annual Report, http:/www.eib.org/attachments/country/femip_annual_report_2014_en.pdf, 1.07.2015.

ENPI (2013), Press pack on Euro-Mediterranean Energy Cooperation: Working together for secure and sustainable energy, http://www.enpi-info.eu/mainmed.php?id type $=3 \& \mathrm{id}=474,20.07 .2015$.

ENPI (2015), Regional project list, http://www.enpi-info.eu/list_projects_med.php?, 20.07.2015.

Ernst \& Young (2015), RECAI, Renewable energy country attractiveness index, Issue 43, http://www.ey.com/Publication/vwLUAssets/Renewable_Energy_Country_Attractiveness_Index_43/\$FILE/RECAI\%2043_March\%202015.pdf, 16.07.2015.

European Commission (2003), On the Development of Energy Policy for the Enlarged European Union, its Neighbours and Partner Countries, Communication from the Commission to the Council and the European Parliament, COM(2003) 262, Brussels.

European Commission (2011a), A Partnership for Democracy and Shared Prosperity with the Southern Mediterranean, Joint Communication to the European Parliament, the Council, the European Economic and Social Committee and the Committee of the Regions, COM(2011) 200, Brussels.

European Commission (2011b), A New Response to a Changing Neighborhood: A Review of European Neighborhood Policy, Joint Communication to the European Parliament, the Council, the European Economic and Social Committee and the Committee of the Regions, COM (2011) 303, Brussels.

European Commission (2011c), On security of energy supply and international cooperation - The EU Energy Policy: Engaging with Partners beyond Our Borders, Communication from the Commission to the European Parliament, the Council, the European Economic and Social Committee and the Committee of Regions, http://eur-lex.europa.eu/legal-content/EN/TXT/ ?uri=URISERV:en0032, 3.07.2015.

European Commission (2012), Supporting closer cooperation and regional integration in the Maghreb: Algeria, Libya, Mauritania, Morocco and Tunisia, Joint Communication to the European Parliament, the Council, the European Economic and Social Committee and the Committee of the Regions, JOIN(2012) 36, Brussels.

European Commission (2014a), In-depth study of European Energy Security Accompanying the document, Communication from the Commission to the Council and the European Parliament: European energy security strategy, $\operatorname{COM(2014)~330,~Brussels.~}$ 
European Commission (2014b), European Neighbourhood and Partnership Instrument 2007-2013 Overview of Activities and Results, https://ec.europa.eu/europeaid/sites/devco/files/overview_of_enpi results_2007-2013_en_0.pdf, 15.06.2015.

European Commission (2015), EU and Algeria to cooperate on energy, https://ec.europa.eu/energy/en/news/eu-and-algeria-cooperate-energy, 1.07.2015.

FEMISE (2012), Renewable Energies and Sustainable Development in the Mediterranean: Morocco and the Mediterranean Solar Plan (msp) Project, Fem 34-02, http://www.uam.es/personal_pdi/economicas/rarce/pdf/fem3402.pdf, 2.07.2015.

GIZ (2013), Support to the Moroccan Solar Plan - the ,APSM" Project, http://www.dlr.de/dlr/Portaldata/1/Resources/documents/2013/giz2013-en-support-moroccan-solar-plan.pdf, 15.06.2015.

Hedberg A. (2015), EU's quest for energy security What role for the Energy Union?, „Policy Brief”. European Policy Centre.

Hafner M., Tagliapietra S. (2013), A New Euro-Mediterranean Energy Roadmap for a Sustainable Energy Transition in the Region, „MEDPRO Policy Paper”, $\mathrm{nr} 3$.

Hong W. M. (2014), An Analysis of North Africa's Capacity to Achieve Renewable Energy Development, „Topics in Middle Eastern and African Economies”, vol. 16, nr 2.

Kausch K. (2013), End of the Southern Neighborhood, „EuroMeSCo Paper”, nr 18.

Kerebel C. (2015), Energia Odnawialna, Parlament Europejski, http://www.europarl.europa.eu/ atyourservice/pl/displayFtu.html?ftuId=FTU_5.7.4.html, 15.06.2015.

Kilpeläinen S. (2013), Energy Relations between the European Union and North Africa?, „Journal of Contemporary European Research", vol. 9, Issue 2.

Komendantova N., Patt A., Barras L., Battaglini A. (2012), Perception of risks in renewable energy projects: The case of concentrated solar power in North Africa, „Energy Policy”, vol. 40.

Komisja Europejska (2007), Mapa drogowa na rzecz energii odnawialnej - Energie odnawialne w XXI wieku: budowa bardziej zrównoważonej przyszłości, Komunikat Komisji do Rady i Parlamentu Europejskiego KOM(2006) 848, Bruksela.

Komisja Europejska (2010), Strategia na rzecz konkurencyjnego, zrównoważonego i bezpiecznego sektora energetycznego, Komunikat Komisji do Parlamentu Europejskiego, Rady, Europejskiego Komitetu Ekonomiczno-Społecznego i Komitetu Regionów, KOM(2010) 639. Bruksela.

Komisja Europejska (2011), Plan dziatania w zakresie energii do roku 2050, Komunikat Komisji do Parlamentu Europejskiego, Rady, Europejskiego Komitetu Ekonomiczno-Spolecznego i Komitetu Regionów, KOM(2011) 885, Bruksela.

Komisja Europejska (2014), Ramy polityczne na okres 2020-2030 dotyczace klimatu i energii, Komunikat Komisji do Parlamentu Europejskiego, Rady, Europejskiego Komitetu Ekonomiczno-Społecznego i Komitetu Regionów, KOM(2014) 15, Bruksela.

MEDREG (2013a), Action Plan 2014-2015-2016, http://maghrenov.eu/file/view/3287/association-of-mediterranean-energy-regulators-action-plan-2014-2015-2016, 3.07.2015.

MEDREG (2013b), Annual Report 2013, http:/www.enpi-info.eu/files/publications/MedregAR2013-4.pdf, 15.07.2015.

InfraMed (2015), http://inframed.com/genesis/, 1.07.2015.

IRENA, REN21, MOFA (2013), MENA Renewables Status Report, http:/www.ren21.net/Portals/0/ documents/activities/Regional\%20Reports/MENA_2013_lowres.pdf, 3.07.2015.

IRENA (2015), Renewable Energy and Jobs: Annual Review 2015, http://www.irena.org/DocumentDownloads/Publications/IRENA_RE_Jobs_Annual_Review_2015.pdf, 15.07.2015. 
Parlament Europejski (2009), Dyrektywa Parlamentu Europejskiego i Rady w sprawie promowania stosowania energii ze źródel odnawialnych uchylajaca dyrektywy 2001/77/WE oraz 2003/30/WE, http://www.ekoefekt.p1/dokumenty/dokument 9.pdf, 2.07.2015.

RCREE (2012a), Algeria Renewable Energy Country Profile, http://www.rcree.org/sites/default/ files/algeria_fact sheet print.pdf, 2.07.2015.

RCREE (2012b), Egypt Renewable Energy Country Profile, http://www.rcreee.org/sites/default/files/ egypt_fact_sheet_print.pdf, 2.07.2015.

RCREE (2012c), Jordan Renewable Energy Country Profile, http://www.rcreee.org/sites/default/ files/jordan_fact_sheet_print.pdf, 2.07.2015.

RCREE (2012d), Lebanon Renewable Energy Country Profile, http://www.rcreee.org/sites/default/ files/lebanon_fact_sheet_print.pdf, 2.07.2015.

RCREE (2012e), Libya Renewable Energy Country Profile, http://www.rcree.org/sites/default/files/ libya_fact_sheet_print.pdf, 2.07.2015.

RCREE (2012f), Morocco Renewable Energy Country Profile, http://www.rcreee.org/sites/default/ files/morocco_fact_sheet print.pdf, 2.07.2015.

RCREE (2012g), Palestine Renewable Energy Country Profile, http://www.rcreee.org/sites/default/ files/palestine_fact_sheet_print.pdf, 2.07.2015.

RCREE (2012h) Syria, http://www.rcreee.org/content/syria, 2.07.2015.

RCREE (2012i), Tunisia Renewable Energy Country Profile, http://www.rcreee.org/sites/default/ files/tunisia_fact_sheet_print.pdf, 2.07.2015.

RCREEE (2015a), http://www.rcreee.org/content/who-we-are, 20.07.2015.

RCREEE (2015b), Arab Future Energy Index - Renewable Energy, http://www.rcreee.org/sites/default/files/afex_re_2015_v2_1st_edition_wo.pdf, 20.07.2015.

RCREEE (2015c), Arab Future Energy Index - Energy Efficiency, http://www.rcreee.org/content/ arab-future-energy-index $\% \mathrm{E} 2 \% 84 \% \mathrm{~A} 2$-afex-2015-energy-efficiency, 20.07.2015.

Tagliapietra S. (2015), The Future of Renewable Energy in the Mediterranean. Translating Potential into Reality, „FEEM Working Paper”, nr 30.

The Future for Renewable Energy in the MENA Region, 2013 Squire Sanders, Clean Energy Pipeline. http://www.cleanenergypipeline.com/Resources/CE/ResearchReports/The $\% 20$ Future $\% 20$ for $\%$ 20Renewable\%20Energy\%20in\%20the\%20MENA\%20Region.pdf, 2.07.2015.

Weissenbacher M. (2012a), Energy Security in the Euro-Mediterranean Region, w: Change and Opportunities in the Emerging Mediterranean, red. S. Calleya, M. Wohlfeld, MEDAC, Malta.

Weissenbacher M. (2012b), Renewable Energy in the Mediterranean Context: State of the Play and Future Perspectives, w: Mediterranean Yearbook 2012, IEMed.

World Bank (2015), Economy Rankings, http:/www.doingbusiness.org/rankings, 20.07.2015.

Varouxakis S. (2013), Renewable Energy in the Euro-Mediterranean Framework, w: Mediterranean Yearbook 2013, IEMed.

Vigotti R. (2013), Renewable Energy Solutions for the Mediterranean. Motivations, priorities and perspectives of a new initiative for the development of renewable energy in the Mediterranean, RES4MED, http://www.res4med.org/uploads/docs/13714569381366116286RES4 MED\%20PRESENTATION-.pdf, 20.07.2015.

Zając J. (2010), Role Unii Europejskiej w regionie Afryki Pólnocnej i Bliskiego Wschodu: Wydawnictwo Uniwersytetu Warszawskiego, Warszawa. 


\title{
Streszczenie
}

Artykuł przedstawia uwarunkowania i perspektyw rozwoju współpracy eurośródziemnomorskiej w zakresie odnawialnych źródeł energii. W pierwszej części, scharakteryzowano cele Unii Europejskiej w sektorze OZE, w drugiej, przedstawiono sytuację energetyczną państw śródziemnomorskiej ze wskazaniem stanu rozwoju sektora OZE, w trzeciej projekty OZE wdrażane w ramach inicjatyw eurośródziemnomorskich, w ezwartej problemy związane z realizacją projektów w sektorze OZE, zarówno w państwach śródziemnomorskich, jak i w ramach programów eurośródziemnomorskich.

Jednym z elementów strategii energetycznej Europy, ściśle związanej z bezpieczeństwem energetycznym, jest dywersyfikacja sektora energetycznego, w tym poprzez zwiększenie produkcji i zużycia energii pochodzącej ze źródeł odnawialnych. Pozyskanie jej planowane jest zarówno z krajowej produkcji poszczególnych państw, jak i poprzez eksport, ze względu na bliskość geograficzną, rozwinięte instytucje współpracy oraz potencjał, państwa śródziemnomorskie zajmują tutaj priorytetowe miejsce. Rozwój sektora odnawialnych źródeł energii w państwach śródziemnomorskich może generować również pozytywne efekty pośrednie dla Europy i stać się bodźcem wzmocnionej współpracy eurośródziemnomorskiej w innych obszarach społeczno-ekonomicznych.

Słowa kluczowe: energia odnawialna, współpraca eurośródziemnomorska, region MENA

\section{The importance of renewable energy in Euro-Mediterranean policy - the determinants and prospects of development}

\begin{abstract}
Summary
The paper presents the conditions and prospects for the development of Euro-Mediterranean cooperation in the field of renewable energy sources (RES). The first part characterises the objectives of the European Union and member states in the field of renewable energy, the second concerns the energy situation in Mediterranean countries, in particular the renewable energy sector, the third presents renewable energy projects implemented within the framework of the Euro-Mediterranean initiative, and part four shows the problems related to the implementation of projects in the renewable energy sector, both in Mediterranean countries as well as within the framework of Euro-Mediterranean programmes.

Europe's energy strategy is closely linked to energy security and diversification of the energy sector by increasing production and consumption of energy from renewable sources. This goal is to be achieved by both domestic production of RES and through trade. Due to their geographical proximity, co-developed institutions and potential, Mediterranean countries are a priority in this strategy. The development of the renewable energy sector in Mediterranean countries may also generate indirect positive effects for Europe and stimulate enhanced Euro-Mediterranean cooperation in other socio-economic fields.
\end{abstract}

Key words: renewable energy, Euro-Mediterranean cooperation, MENA region 
